CRYOCOOLERS 8 


\title{
CRYOCOOLERS 8
}

\author{
Edited by
}

\section{R. G. Ross, Jr.}

Jet Propulsion Laboratory Californa Institute of Technology

Pasadena, California

Springer Science+Business Media, LLC 


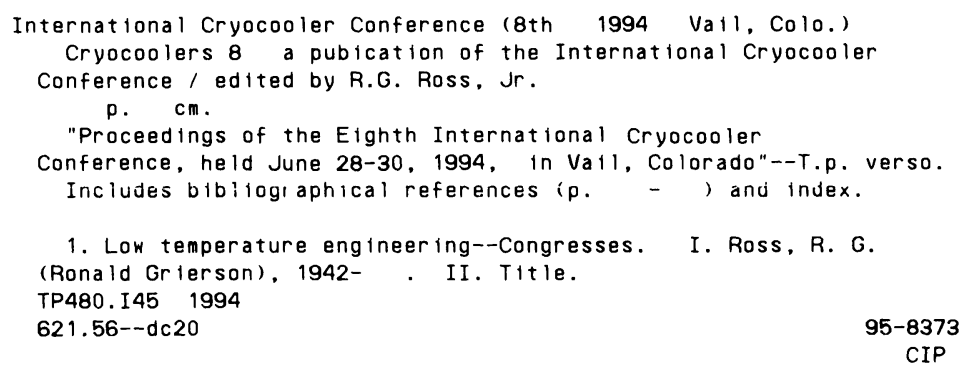

Proceedings of the 8th International Cryocooler Conference, held June 28-30, 1994 . in Vail, Colorado

\author{
ISBN 978-1-4757-9890-6 \\ ISBN 978-1-4757-9888-3 (eBook) \\ DOI 10.1007/978-1-4757-9888-3
}

(c) Springer Science+Business Media New York 1995 Originally published by Plenum Press, New York in 1995 Softcover reprint of the hardcover 1st edition 1995

\title{
10987654321
}

\section{All rights reserved}

No part of this book may be reproduced, stored in a retrieval system, or transmitted in any form or by any means, electronic, mechanical, photocopying, microfilming, recording, or otherwise, without written permission from the Publisher 


\section{Preface}

The last few years have witnessed a substantial maturing of long life Stirling-cycle cryocoolers built upon the heritage of the flexure-bearing cryocoolers from Oxford University, and have seen the emergence of mature pulse tube cryocoolers competing head-to-head with the Stirling cryocoolers. Hydrogen sorption cryocoolers, Gifford-McMahon cryocoolers with rare earth regenerators, and helium Joule-Thomson cryocoolers have also made tremendous progress in opening up applications in the $4 \mathrm{~K}$ to $10 \mathrm{~K}$ temperature range. Tactical Stirling cryocoolers, now commonplace in the defense industry, are finding application in a number of costconstrained commercial applications and space missions, and are achieving ever longer lives as they move to linear-drive, clearance-seal compressors.

Building on this expanding availability of commercially viable cryocoolers, numerous new applications are being enabled; many of these involve infrared imaging systems, and hightemperature superconductors in the medical and communications fields. The vibration sensitivity of many of the infrared and medical imaging applications has led to the recognition that cryocooler-generated vibration and EMI is a critical performance parameter for these applications. In response, advanced closed-loop active vibration control systems have been developed and are being delivered to their first users. Application experiments, designed to explore, troubleshoot and resolve product integration issues, are occurring on an ever widening front, particularly in the fields of infrared imaging and spectroscopy, gamma-ray spectroscopy, and high-temperature superconductor applications. An important lesson is that integrating cryogenic systems requires care and thoughtfulness in a broad range of engineering and scientific disciplines.

This book draws upon the work of many of the international experts in the field of cryocoolers, and is based on their contributions at the 8th International Cryocooler Conference, held in Vail, Colorado, in June 1994. The program of this conference consisted of 107 papers. Of these, 93 are published here in Cryocoolers 8 . Although this is the eighth meeting of the conference, which has met every two years since 1980, this is the first time the authors' works have been made available to the public in hardcover book form. As such, this book is the first volume of what we hope will be a series of professional texts for users and developers of cryocoolers. Previous proceedings of the International Cryocooler Conference have been published over the years as informal reports by the particular government organization sponsoring the conference -- typically a different organization for each conference. A listing of previous conference proceedings is presented in the Proceedings Index, at the rear of this book. Most of the previous proceedings were printed in limited quantity and are out of print at this time.

Because this book is designed to be an archival reference for users of cryocoolers as much as for developers of cryocoolers, extra effort has been made to provide a thorough Subject Index that covers the referenced cryocoolers by type and manufacturer's name, as well as by the scientific or engineering subject matter. Extensive referencing of test and measurement data is included in the Subject Index under a wide variety of performance topics. Examples include refrigeration performance data, complete cryocooler characterization test data, vibratıon and EMI 
measurements, and qualification and life test experience. Application and integration experience is also highlighted by specific index entries. To aide those attempting to locate a particular contributor's work, a separate Author Index is also provided, listing all authors and co-authors. Contributing organizations are listed in the Subject Index to assist in finding the work of a known institution, laboratory, or cryocooler manufacturer.

The content of the book is organized into 14 chapters by cryocooler type, starting with Stirling cryocoolers, pulse tube cryocoolers, and their associated drive electronics. Next, Brayton, Joule-Thomson and sorption cryocoolers are covered in a progression of lowering temperatures. Low-temperature regenerators for Gifford-McMahon cryocoolers and magnetic refrigerators in the 4 to $10 \mathrm{~K}$ range are covered next. The last three chapters deal with cryocooler integration technologies and experience to date in a number of representative applications. These applications are divided by temperature into those in the 2-20 K range, and those in the 50-100 $\mathrm{K}$ range. The articles in these last three chapters contain a wealth of information for the potential user of cryocoolers, as well as for the developer.

It is hoped that this book will serve as a valuable source of reference to all those faced with the challenges of taking advantage of the enabling physics of cryogenics temperatures. The expanding availability of low-cost, reliable cryocoolers has the potential of making major advances in a number of fields.

Ronald G. Ross, Jr.

Jet Propulsion Laboratory

California Institute of Technology 


\section{Acknowledgments}

The International Cryocooler Conference Board wishes to thank the Jet Propulsion Laboratory, California Institute of Technology, which hosted the 8th ICC, and to express its deepest appreciation to the Conference Organizing Committee, whose members dedicated many hours to organizing and managing the conduct of the Conference. Members of the Organizing Committee and Board for the 8th ICC include:

\author{
CONFERENCE CHAIRMAN \\ Ron Ross, Jet Propulsion Lab \\ CONFERENCE COORDINATOR \\ Pat Mclane, set Propulsıon Lab \\ ADMIN ASSISTANT \\ Sue Hartman, Jet Propulsıon Lab \\ PROGRAM CHAIRMAN \\ Peter Jones, Aerospace corp. \\ CONFERENCE SECRETARY \\ Jill Bruning, Nichols Research \\ PUBLICATIONS \\ Marko Stovanof, AF Phillips Lab \\ LOCAL ARRANGEMENTS \\ Ray Radebaugh, NIST
}

\author{
PROGRAM COMMITTEE \\ Peter Jones, Aerospace corp. \\ Willy Gully, Ball Aerospace \\ Al Johnson, Aerospace Corp. \\ Dean Johnson, Jet Propulsion Lab \\ Peter Kittel, NASA/ARC \\ Jim Shaffer, USA Night Vision Lab \\ Dodd Stacy, Creare \\ ADVISORY BOARD \\ John Barclay, Univ. of Victoria \\ Stephen Castles, NASA/CSFC \\ Ray Radebaugh, NIST \\ Hiroshi Nagano, Toyama Univ. \\ Ralph Longsworth, $A P D$ \\ Martin Nisenoff, NRL \\ Joseph Smith, MIT \\ Michael Superczynski, DTRC \\ Klaus Timmerhaus, $U$. of Colorado \\ Paul Sheihing, DOE \\ Peter Kerney, $\mathrm{CTI}$ \\ George Robinson, NRC
}

In addition to the Committee and Board, key staff personnel made invaluable contributions to the preparations and conduct of the conference and to this publication. Special recognition is due N. Angel, N. Maclean, H. Mycroft, W. Saba, and R. Turco. 


\section{Contents}

Space Stirling Cryocooler Developments

Development for Space Use of BAe's Improved Single-Stage Stirling

Cycle Cooler for Applications in the Range $50-80 \mathrm{~K}$.

B.G. Jones, British Aerospace Space Systems, Bristol, ENGLAND

Space Cryogenic Refrigerator System (SCRS) Thermal Performance

Test Results . . . . . . . . . . . . . . . . . . . . . . . . . 13

I.E. Spradley and W.G Foster, Lockheed, Palo Alto, CA

Test Results for the Single-Stage Ball Flight Prototype Cooler . . . . . . . 23

W.J. Horsley, E.F. Hicks, W.C. Kiehl, D.W. Simmons, D.J. Taylor,

E.E. Wells and J A. Wells, Ball Aerospace, Boulder, CO

Long-Life Cryocooler Development Program for ASTER . . . . . . . . . 35

M. Kawada and H. Fujisada, Electrotechnical Laboratory, Ibaraki, JAPAN

Development of a Stirling Cryocooler Using Hydrodynamic

Gas Bearings . . . . . . . . . . . . . . . . . . . . . . 47

L. Duband, A. Ravex and P. Rolland, CEA, Grenoble, FRANCE

Design, Performance, and Testing of the Lockheed-Developed

Mechanical Cryocooler . . . . . . . . . . . . . . . . . . . 55

T.C. Nast, P.J. Champagne, D Isaac, G.M. Pryor, R L. von Savoye and

$L$ G. Naes, Lockheed MSC, Palo Alto, CA

Improved Standard Spacecraft Cryocooler Life Test for Space-Based

Infrared Surveillance . . . . . . . . . . . . . . . . . . . . . . . 69

J.M. Wakugawa, H Haque and K.D. Price, Hughes Aircraft Company,

El Segundo, $C A$

Development of Stirling Cryocooler for Use In Space . . . . . . . . . . . 77

T. Fukuda, T. Tsuchiya, M. Ishii and T. Takakusagi, Hitachi, Ltd., Ibaraki, JAPAN;

M. Furukawa, National Space Devel. Agency of Japan, Ibaraki, JAPAN

NASA/GSFC $80 \mathrm{~K}$ Long-Life, Low Vibration Mechanical Cryocooler

Performance Test Program Results . . . . . . . . . . . . . . . 85

L.G. Naes, G.M. Pryor, I.A. Spradley, D. Isaac and R.L. von Savoye,

Lockheed MSC, Palo Alto, CA; L.M. Sparr NASA GSFC, Greenbelt, MD 
Multi-Stage Cryocooler for Space Applications . . . . . . . . . . . . . . . . 93

H. Carrington, W.J. Gully, M. Hubbard and C. Varner, Ball Aerospace.

Boulder, CO; P. Arter, NCAR, Boulder, CO

30 K Diaphragm Stirling Cryocooler Demonstration . . . . . . . . . . 103

W.D. Stacy and W.R. Baschnagel, Creare, Hanover, NH; D. Lusster,

Fairchild Space, Greenbelt, MD

\section{Low-Cost Tactical Stirling Cryocoolers}

Hughes Long-Life linear Stirlings: A Status Report

G.R. Pruitt, Hughes Electron Dynamics Div., Torrance, CA

Linear Drive Stirling Cryocoolers: Qualification and

Life Testing Results

R.M. Rawlings, C.E. Granger, III and G.W. Hinrichs, Texas Instruments,

Inc., Dallas, $T X$

Dual Opposed Piston Stirling Cryocoolers for IR Systems

R. Narayan, Magnavox Electro-Optics, Mahwah, NJ

Space Qualification Program of a Signaal USFA Tactical Cooler

for the Mars 1996 Space Mission . . . . . . . . . . . .

A. Chardin, Inst. D'Astrophysique Spatiale, Orsay, FRANCE; D. Féger,

Cryotechnologies, Blagnac, FRANCE; and D. Verbeek, Signaal USFA,

Eindhoven, The Netherlands

Performance Characterization of the Sunpower Cryocooler

G.T. Smedley and R.G. Ross, Jr., JPL, Pasadena, CA; D.M. Berchowitz,

Sunpower, Inc., Athens, $\mathrm{OH}$

Adaptation of Tactical Cryocoolers for Short Duration Space-Flight

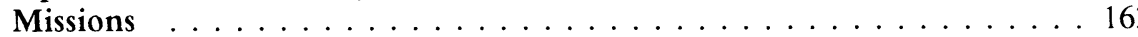

L. Sparr, M. Sartor and R. Boyle, NASA/GSFC, Greenbelt, MD; S. Banks

and E. James, McDonnell Douglas Corp., Seabrook, MD

\section{Stirling Cryocooler Performance Comparisons}

JPL Cryocooler Development and Test Program Overview

R.G. Ross, Jr., JPL, Pasadena, CA

Thermal Performance of Stirling-Cycle Cryocoolers: A Comparison

of JPL-Tested Coolers . . . . . . . . . . . . . . . . . . . . . . 185

G.T. Smedley, G.R. Mon, D.L. Johnson and R.G. Ross, Jr., JPL, Pasadena, CA

Vibration Characteristics of Stirling-Cycle Cryocoolers for Space

G.R. Mon, G.T. Smedley, D.L. Johnson and R.G. Ross, Jr., JPL, Pasadena, CA

Cryocooler Electromagnetic Compatibility

D.L. Johnson, G.T. Smedley, G.R. Mon, R.G. Ross, Jr. and P. Narvaez,

JPL, Pasadena, CA

NASA/GSFC Cryocooler Test Program Results for FY93/94 .

L. Sparr, M. Sartor, R. Boyle, S. Castles and T. Cygnarowicz, NASA/GSFC, Greenbelt, MD; S. Banks and E. James, McDonnell Douglas Corp., Seabrook, $M D$; and V. Arillo and R. Cory, Hughes-STX, Greenbelt, MD 
BAe $80 \mathrm{~K}$ Cryocooler Life Test for Space-Based Infrared

Surveillance

$J M$ Wakugawa and H. Haque, Hughes Aircraft Co., El Segundo, CA, and

R.A Orsim, TRW, Redondo Beach, CA

\section{Stirling Cryocooler Components and Theory}

A Method for Intrinsic Temperature Regulation of

Miniature Stirling Coolers

$M$ Bareiss, A. Fiedler, $H$ Laschutza and $G$. Schellenberger, $A E G$

Akttengesellschatt, Heillbromn. GERMANY

Regenerator Optimization for Stirling Cycle Refrigeration, II . . . . . . 247

S.A. Colgate, LANL, Los Alamos, NM

Friction Factors of Stacks of Perforated Regenerator Plates . . . . . . . . . . 259

S. Yoshuda, K.V. Ravikumar and T H.K. Frederking, UCLA, Los Angeles, CA

Experimental Analysis of Heat Transfer Characteristics and Pressure

Drop through Screen Regenerative Heat Exchangers . . . . . . . . . . . . . 269

J.L. Wiese, USAF Phillips Lah, Kirtland AFB, NM; and W.J. Bowman,

Air Force Inst. of Tech., Wright-Patterson AFB, $\mathrm{OH}$

Sage: Object-Oriented Software for Cryocooler Design

$D$ Gedeon, Gedeon Assoc., Athen., $\mathrm{OH}$

Design Optimization of Linear-Arm Flexure Bearings

E. Marquardt and $R$ Radebaugh, NIST, Boulder, CO

Spiral Flexure Bearing

T.E. Wong, R.B. Pan, H.D. Marten, C. Sve, L. Galvan and T S. Wall,

The Aerospace Corp , El Segundo, CA

\section{Pulse Tube Cryocooler Developments}

Demonstration of a High Performance $35 \mathrm{~K}$ Pulse Tube

Cryocooler . . . . . . . . . . . . . . . . . . . . . . 313

W.W. Burt and C.K. Chan, TRW, Redondo Beach, CA

Experimental Investigation of a Linear, Orifice Pulse Tube

Expander . . . . . . . . . . . . . . . . . . . . . . . . 321

$S$ C. Soloskl and F N. Mastrup, Hughes Aircraft Co., El Segundo, CA

Miniature Long-Life Space-Qualified Pulse Tube and

Stirling Cryocoolers . . . . . . . . . . . . . . . . . . . . . . . . . . . 329

E. Tward, C.K. Chan, J. Raah, R Orsimı, C. Jaco and M Petach, TRW,

Redondo Beach, CA

Two-Stage Pulse Tube Refrigerator for 20 K Operation . . . . . . . . . . . . 337

$Y$ Ohtani, M. Takahash. T Kuriyama and H. Nakagome, Toshba R\&D,

Kanagawa, JAPAN; J. Gao, H. Tanuda and Y. Matsubara, Nihon Universaty,

Chiba, JAPAN; and M Narita, H. Murakami and H Okuda, Inst. of Space

and Astron. Science, Kanagawa, JAPAN

Multi-Stage Pulse Tube Refrigerator for Temperatures

below $4 \mathrm{~K}$

Y. Matsubara and J.L. Gao, Atomic Energy Research Institute. Nohon

Unuversity, Funabashi, JAPAN 
Cooling Performance of a Prototype Miniature Pulse Tube

Refrigerator with a Flexure Spring Compressor . . . . . . . . . . . 353

T. Haruyama and H. Inoue, KEK, Ibaraki, JAPAN

\section{Pulse Tube Cryocooler Components and Theory}

Steady Secondary Momentum and Enthalpy Streaming in the

Pulse Tube Refrigerator . . . . . . . . . . . . . . . . . . . . . . . . . . 359

J.M. Lee and P. Kittel, NASA Ames Research Center, Moffett Field, CA; K.D. Timmerhaus, Univ. of Colorado, Boulder, CO; R. Radebaugh, NIST, Boulder, $\mathrm{CO}$

A Model for Analyzing Ideal Double Inlet Pulse Tube

Refrigerator

A. Hofmann, Kernforschungszentrum Karlsruhe, GERMANY; S. Wild, Universitat Karlsruhe, GERMANY

Effect of Pressure Wave Form on Pulse Tube Refrigerator

Performance . . . . . . . . . . . . . . . . . . . . . 383

F. Giebeler, G. Thummes and C. Heiden, Justus-Liebig-Univ.

Giessen, GERMANY

Compact Four-Valve Pulse Tube Refrigerator in Coaxial

Configuration . . . . . . . . . . . . . . . . . . . . . . . . 395

J. Blaurock, R. Hackenberger, P. Seidel and M. Thurk, Friedrich Schiller

University, Jena, GERMANY

Pressure and Temperature Oscillations of Working Gas in a

Pulse Tube Refrigerator . . . . . . . . . . . . . . . . . . . . . . . . . . 403

M. Shiraishi, Mechanical Engineering Lab, MITI, Ibaraki, JAPAN; K. Seo

and M. Murakami, Univ. of Tsukuba, Ibaraki, JAPAN

Analytical Model and Experimental Results of a Miniature

Pulse Tube Refrigerator . . . . . . . . . . . . . . . . . . . . . . 411

M. David and J-C. Maréchal, Ecole Normale Supérieure, Paris, FRANCE

\section{Cryocooler Vibration Control and Drive Electronics}

MOPITT Stirling Cycle Cooler and Cooler Drive Electronics

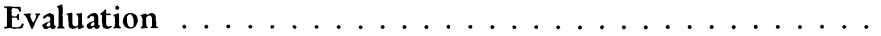

E.L. Cook, COM DEV Atlantic, Moncton, CANADA; J.R. Drummond and

G.S. Mand, Univ. of Toronto, Toronto, CANADA; R. Colley, Canadian

Space Agency, Ottawa, CANADA; and B. Clappier and T. McGinnis,

Lockheed, Palo Alto, CA

Development and Test of Low Vibration Cryocooler Electronics

G.D. Salapski, Z.F. Backovsky and T.H. Weight, Rockwell International, Anaheim, $C A$

Active Multi-Axis Vibration Cancellation for Split-Stirling

Cryocoolers

S.A. Collins and J.D. Paduano, MIT, Cambridge, MA; and A.H. von Flotow,

Hood Technology Corp., Hood River, OR

Flight Hardware Implementation of a Feed-Forward Vibration

Control System for Space Flight Cryocoolers

R. Boyle, L. Sparr and T. Gruner, NASA/GSFC, Greenbelt, MD; E. James and

S. Banks, McDonnell Douglas, Seabrook, MD; J. Wilmot and V. Arillo, Hughes-

STX, Greenbelt, MD; and T. Gibboney, Fairchild Space Corp., Greenbelt, MD 
STRV Cryocooler Tip Motion Suppression . . . . . . . . . . . . . . . 455

R.J. Glaser, R.G. Ross, Jr. and D.L. Johnson, JPL, Pasadena, CA

Reduction of the Vibration Generated by Stirling Cryocoolers

Used for Cooling a High-Tc SQUID Magnetometer . . . . . . . . . . . . . 465

J.F.C. Verberne, P.C. Bruins, P.J. van den Bosch and H.J.M. ter Brake,

Univ. of Twente, The Netherlands

Implementation and Test of the Control Algorithms for a

Diaphragm Stirling $30 \mathrm{~K}$ Cryocooler . . . . . . . . . . . . . . . . . 475

C. Konkel, T. Gibboney and K. Ha, Fairchild Space, Greenbelt, MD;

and R. Boyle, NASA/GSFC, Greenbelt, MD

NASA IN-STEP Cryo System Experiment Flight Electronics for

Spacecraft Cryocooler Control and Characterization

P.M. Mayner and B.F. Wolf, Hughes Aircraft Co., El Segundo, CA

\section{Brayton and J-T Cryocooler Developments}

Single-Stage Reverse Brayton Cryocooler: Performance of the

Engineering Model

W.L. Swift, Creare, Hanover, NH

Miniaturization of Components for Low Capacity Reverse Brayton

Cryocoolers

J.A. McCormick, W.L. Swift and H. Sixsmith, Creare, Hanover, NH

Development Status of a $2.5 \mathrm{~K}-4 \mathrm{~K}$ Closed-Cycle Cooler Suitable

for Space Use . . . . . . . . . . . . . . . . . . . . . . . . . . . . 517

A.H. Orlowska, T.W. Bradshaw and J. Hieatt, Rutherford Appleton Laboratory, ENGLAND

Qualification of a $4 \mathrm{~K}$ Mechanical Cooler for Space Applications . . . . . . 525 B.G. Jones and D.W. Ramsay, British Aerospace Space Systems, Bristol, ENGLAND

80 K Closed-Cycle Throttle Refrigerator . . . . . . . . . . . . . . . . . . 537

R.C. Longsworth, M.J. Boiarskl and L.A. Klusmier, APD Cryogenics Inc., Allentown, PA

Joule-Thomson Cryocooler Development at Ball Aerospace . . . . . . . . . 543

$R$. Levenduski and R. Scarlottl, Ball Aerospace, Boulder, CO

Phase Equilibria in Cryogenic Mixtures: Part II . . . . . . . . . . . . . . . . . 559

L.B. Robinson, UCLA, Los Angeles, CA

\section{Sorption Cryocooler Developments}

Development of an Advanced Sorption Compressor and Its

Application in a $125 \mathrm{~K}$ Cryocooler

J.A. Alvarez, R J. Krylo, R.D. Snapp, C. Weston, P. Sywulka and G.C Abell,

Aerojet Electrontcs Plant, Azusa, CA

Dynamic Simulation of a Periodic $10 \mathrm{~K}$ Sorption Cryocooler

P. Bhandari, J. Rodriguez, S Bard and L. Wade, JPL, Pasadena, CA

Fabrication and Testing of the Metal Hydride Sorbent Bed Assembly

for a Periodic $10 \mathrm{~K}$ Sorption Cryocooler.

R.C. Bowman, Jr., D.R. Gilkinson, R.D. Snapp, G.C. Abell, B.D. Freeman

and E.L. Ryba, Aerojet Electronics Plant, Azusa, CA; and L.A. Wade, JPL,

Pasadena, $C A$ 
Ground Testing of a $10 \mathrm{~K}$ Sorption Cryocooler Flight

Experiment (BETSCE) _. . . . . . . . . . . . . . . . . . . . . . . . 609

S. Bard, J. Wu, P. Karlmann, P. Cowgill, C. Mirate and J. Rodriguez, JPL,

Pasadena, $C A$

Component Reliability Testing of Long-Life Sorption Cryocoolers

S. Bard, J. Wu, P. Karlmann, C. Mirate and L. Wade, JPL, Pasadena, CA

\section{Magnetic Refrigerators and Low-Temperature Regenerators}

Development of a Magnetic Refrigerator Operating between

$2 \mathrm{~K}$ and $10 \mathrm{~K}$

A. Kashani, Atlas Scientific, Sunnyvale, CA; B P.M. Helvensteijn, Sterling

Federal Systems, Palo Alto, CA; F.J. McCormack and A.L. Spivak, Trans-Bay

Electronics, Richmond, CA; and P. Kittel, NASA ARC, Moffett Ficld, CA

Investigation of a Magnetically Augmented Cryogenic Refrigerator

J.L. Smith, Jr. and G.F. Nellis, MIT, Cambridge, MA

Design of Active Magnetic Regenerative Stage Interfacing

to a G-M Cryocooler

C.B. Zimm, A.G. Jastrab and J W. Johnson, Astronautics Tech. Center, Madison, WI

Experimental Results of an Efficient Active Magnetic Regenerator

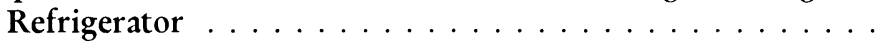

A.A. Wang, J.W. Johnson, R.W. Niemi, A A. Sternherg and C.B. Zımm,

Astronautics Tech. Center, Madison, WI

Excellent Character of Multi-Layer Type Magnetic Regenerator

near $4.2 \mathrm{~K} \ldots \ldots \ldots \ldots \ldots \ldots$

T. Hashimoto, T. Tsukagoshi, H. Nitta and M. Yabuki, Tokyo Institute of

Technology, Tokyo, JAPAN; T. Kuriyama and H. Nakagome, Toshiba $R \& D$

Center, Kanagawa, JAPAN

New Ternary Magnetic Lanthanide Regenerator Materials for

the Low-Temperature Stage of a Gifford-McMahon (G-M)

Cryocooler

K A. Gschneidner, V.K. Pecharsky and M. Gailloux, Ames Lab, Lowa State

University, Ames, IA

\section{Generic Cryocooler Integration Technologies}

Cryogenic Systems Integration Model (CSIM)

M. Donabedian, D.S. Glatster and M.D. Bernstein, The Aerospace Corp.,

El Segundo, $C A$

Cryocooler Coldfinger Heat Interceptor . . . . . . . . . . . . . . . . . . 709

D.L. Johnson and R.G. Ross, Jr., JPL, Pasadena, CA

Cryogenic Capillary Pumped Loops: A Novel Cryocooler

Integration Technology . . . . . . . . . . . . .

B. Cullumore, Cullimore and Ring Tech., Littleton, CO; E. Kroliczek,

OAO Corp., Greenbelt, MD; and J Ku, NASA/GSFC, Greenbelt, MD

A Thermal Switch for Use at Liquid Helium Temperature in

Space-Borne Cryogenic Systems

L. Duband, CEA, Grenoble, FRANCE 
Emerging Technologies for Cryocooler Interfaces

J.H. Rosenfeld, Thermacore, Inc., Lancaster, PA; D.A. Wolf, Dynatherm

Corp., Hunt Valley, MD; and M.T. Buchko, NASA GSFC, Greenbelt, MD

Modeling Thermal Contact Resistance

P. Kittel, NASA Ames Research Center, Moffett Field, CA

Perpendicular Loading as a Solution to the Problem of Building

an All Purpose Cryogenic Interface . . . . . . . . . . . . . 765

J. Hess, Cryostar Assoc., Tucson, $A Z$

\section{Cryocooler Applications Experience in the 2-20K Range}

The Test Results of On-Board Refrigeration System with

Low-Temperature Buffer Tank . . . . . . . . . . . . . . . . . . . . 777

$T$ Herai and K. Nagashima, Ralway Tech. Research Inst., Tokyo, JAPAN

A 4 K G-M Refrigerator for Direct Cooling of a 6 T NbTi

Superconducting Magnet System . . . . . . . . . . . . . . . . . 785

$T$ Kuriyama, Y. Ohtani, M Takahashi and H. Nakagome, Toshiba R\&D

Center, Kanagawa, JAPAN

Improved Seal for a $4 \mathrm{~K}$ Gifford-McMahon Cryocooler

$R$ L. Plambeck, Univ. of California, Berkeley, CA

Shock and Vibration Test of a Two Stage Gifford-McMahon

Cryocooler for Use in a U.S. Navy Magnetic

Minesweeping System

E. Roth, Vector Research Co, Rockville, MD; G. Green and J. Chafe,

NSWC, Annapoll., MD

Finite Element Shock Analysis of a Cryogenic Refrigerator

E.A Schroeder and G. Green, NSWC Div., Bethesda, MD; G. Green,

NSWC, Annapolis, MD

Variable Temperature Thermal Conductivity and Conductance

Measurements Using a Gifford-McMahon Cryocooler . . . . . . . . . . . . 823

J.D. Walters, TH. Fikse and T L. Cooper, Annapolis Detachment,

CDNSWC, Annapolis, MD

Application of Boreas Cryocoolers

A G. Liepert and J.A. Crunkleton, Boreas, Inc., Burlington, MA

Active Refrigeration for Space Astrophysics Missions

$L$ A. Wade, JPL, Pasadena, CA

\section{Cryocooler Applications Experience in the 50-100K Range}

Design and Verification of Stirling Cooler Interfaces Suitable for

Long-Lifetime, Space-Borne Sensor Systems

R.F. Arentz, F.A Eriksen, R A. Hopkins, S.J Nieczkoski, D.A. Payne

and J F. Siehert, Ball Aerospace, Boulder, CO

Lessons Learned during the Integration Phase of the NASA

IN-STEP Cryo System Experiment . . . . . . . . . . . . . . . . . . . . . 869

R.S. Sugimura, JPL, Pasadena, CA; S.C. Russo and D.C. Gilman, Hughes

Aurcraft Co., El Segundo, CA 
Ricor K506B Cryocooler Performance during the Clementine

Mission and Ground Testing: A Status Report

R.E. Priest, J.A. Robinson, T.L. Clark, D.R. Hadley and N.R. Sewall, LLNL, Livermore, $C A$

High-Temperature Superconducting Space Experiment II (HTSSE II)

Overview and Preliminary Cryocooler Integration Experience

T. Kawecki, Naval Research Lab, Washington, DC

The Application of Cryocoolers for Cooling a High-Tc SQUID

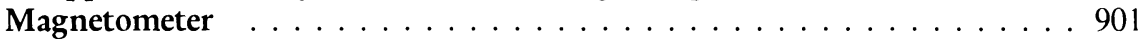

P.J. van den Bosch, W.A.M. Aarnink, H.A. de Boer, H.J. Holland,

H.J.M. ter Brake and H. Rogalla, Univ. of Twente, The Netherlands

Cryocoolers and High-Temperature Superconductors: Advancing

toward Commercial Applications . . . . . . . . . . . . . . . . 913

M. Nisenoff, NRL, Washington, $D C$

NASA Advanced Refrigerator/Freezer Technology Development

Project Overview

J.E. Cairelli, NASA LeRC, Cleveland, $O H$

The Development and Verification of a Cryogenic Phase Change

Thermal Storage Unit for Spacecraft Applications

D.S. Glaister, K.D. Bell and M. Bello, The Aerospace Corp, El Segundo,

CA; and M. Stoyanof, USAF Phillips Lab, Albuquerque, NM

ICE (Integrated Cooler Experiment) for COOLSAT

B.G. Williams and J.C. Batty, Utah State Univ., Logan, UT

Commercial Low Cost Cryogenic Packaging for Linear

Micro-Coolers . . . . . . . . . . . . . . . . . . . . . . . . . . . . . . . . . . 949

T.H. Clynne, J.R. McCoy and M. Kimak, Infrared Components Corp.,

Utica, $N Y$

Indexes

Proceedings Index . . . . . . . . . . . . . . . . . . 953

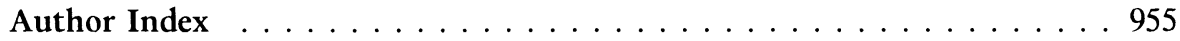

Subject Index $\ldots \ldots \ldots \ldots$. . . . . . . . . . . . . . . 957 